\title{
Profil Lipid Penderita Acquired Immunodeficiency Syndrome (AIDS) di Kota Bau-Bau Sulawesi Tenggara
}

\author{
Angriani Fusvita ${ }^{1}$, Firdayanti ${ }^{2}$, Waode Sartika ${ }^{3}$ \\ Program Studi Analis Kesehatan, Politeknik Bina Husada Kendari 1,2,3 \\ angrianif@gmail.com ${ }^{1}$
}

\begin{abstract}
Diajukan 20 Maret 2019 Diperbaiki 14 Mei 2019 Diterima 19 Agustus 2019
ABSTRAK

Latar Belakang: Berdasarkan data kasus kematian akibat AIDS di Provinsi Sulawesi Tenggara ditemukan jumlah kematian AIDS tertinggi di kota Bau-bau. Gangguan terkait metabolik banyak dijumpai pada orang yang mengidap HIV/AIDS yaitu resistensi insulin, lipodistrofi, dan dislipidemia. Penelitian yang dilakukan oleh Adewole et al, (2010) menjelaskan bahwa pada orang yang terinfeksi HIV telah menunjukkan berbagai kelainan lipid.

Tujuan: Mengetahui profil lipid penderita AIDS di kota Bau-bau Sulawesi Tenggara.

Metode: Jenis penelitian adalah deskriptif secara cross-sectional study dengan melakukan pemeriksaan profil lipid pada penderita AIDS sebanyak 29 orang sebagai sampel di kota Bau-bau

diperoleh dengan metode accidental sampling. Data dianalisis secara deskriptif.

Hasil: Kadar HDL pada penderita AIDS didapatkan hasil yang rendah $(\leq 45 \mathrm{mg} / \mathrm{dL})$ sebanyak 29 orang (100\%). Kadar Kolesterol pada penderita AIDS didapatkan hasil yang normal (s $200 \mathrm{mg} / \mathrm{dL}$ ) sebanyak 29 orang (100 \%). Kadar LDL pada penderita AIDS yang normal $(\leq 130 \mathrm{mg} / \mathrm{dL})$ sebanyak 29 orang (100\%). Kadar trigliserida pada penderita AIDS didapatkan hasil yang tinggi $(\geq 200$ $\mathrm{mg} / \mathrm{dL}$ ) sebanyak 29 orang (100\%).

Kesimpulan: Profil lipid pada penderita AIDS didapatkan kadar trigliserida yang tinggi, kadar LDL dan kolesterol yang normal, serta kadar HDL rendah.
\end{abstract} dengan metode continuous flow analyzer. Sampel

Kata Kunci: HIV; AIDS; profil lipid; kota Bau-bau

\section{ABSTRACT}

Background: Based on data on cases of deaths from AIDS in Southeast Sulawesi Province, the highest number of AIDS deaths was found in the city of Bau-bau. Metabolic related disorders are common in people with HIV / AIDS, namely insulin resistance, lipodystrophy, and dyslipidemia. Research conducted by Adewole et al. (2010) explains that in people infected with HIV, they have shown various lipid abnormalities.

Objective: to find out the lipid profile of AIDS patients in the city of Bau-bau Southeast Sulawesi.

Method: This type of research is descriptive in crosssectional study by examining lipid profiles in AIDS patients as many as 29 people as samples in the city of
Bau-bau with a continuous flow analyzer method. Samples are obtained by accidental sampling method. Data were analyzed descriptively.

Results: HDL levels in AIDS patients were low ( $\leq 45 \mathrm{mg} /$ $d L)$ as many as 29 people (100\%). Cholesterol levels in AIDS patients have normal results $(\leq 200 \mathrm{mg} / \mathrm{dL})$ as many as 29 people (100\%). LDL levels in normal AIDS patients ( $\leq 130 \mathrm{mg} / \mathrm{dL}$ ) are 29 people (100\%). Triglyceride levels in AIDS patients were high (200 mg / $d L)$ as many as 29 people (100\%).

Conclusion: Lipid profiles in AIDS patients found high triglyceride levels, normal LDL and cholesterol levels, and low HDL levels in AIDS patients

Keywords: HIV; AIDS; lipid profile; Bau-bau city 


\section{PENDAHULUAN}

Humman ImmunodeficiencyVirus (HIV) merupakan virus yang menurunkan sistem kekebalan tubuh (Haringi et al 2016, (Ainun, Febrina, \& Wahyuni, 2016)). Orang yang terkena virus ini akan menjadi rentan terhadap berbagai infeksi yang menyebabkan penyakit Acquired Immunodeficiency Syndrom(AIDS). AIDS saat ini merupakan salah satu bencana kesehatan terbesar di dunia (Ntim,2016).

Acquired Immunodeficiency Syndrome (AIDS) adalah penyakit yang ditandai adanya kelainan kompleks dari sistem pertahanan seluler (Sudikno et al, 2010). AIDS ditandai sebagai manifestasi klinis agen Human Immunodeficiency Virus (HIV), dengan demikian diakui sebagai masalah kesehatan serius di tingkat dunia karena penekanannya terhadap imunitas, dimediasi oleh sel $\mathrm{T}$, sehingga membuat individu rentan terhadap infeksi oportunistik (Santos et al, 2016).

Infeksi yang menular menyerang sel darah putih khusus yang dinamakan $T$ lymphosites dimana berfungsi sebagai perlawanan tubuh dari serangan infeksi. Apabila sel $\mathrm{T}$ mengalami kerusakan yang signifikan, maka tidak terjadi perlawanan terhadap sebagian besar kuman yang menginfeksi tubuh. Akibatnya, tubuh mulai ditulari infeksi yang luar biasa dan menetap di dalam tubuh. Infeksi tersebut terkadang menyerang orang, tetapi tidak pernah berkembang (Shinta, 2011).

Kasus kematian akibat AIDS di Provinsi Sulawesi Tenggara tahun 2012 sebanyak 28 kasus, terdiri dari 17 orang laki-laki dan 11 orang perempuan. Jumlah kematian AIDS tertinggi terjadi di Kota Bau-Bau dengan 9 kasus kematian. Kota Kendari 5 kasus kematian, Kabupaten Buton, dan Kabupaten Muna masing-masing 4 kasus kematian (Dinkes Sultra, 2012).

Kecenderungan jumlah kasus AIDS lebih banyak ditemukan pada laki-laki kemungkinan disebabkan oleh mobilitas lakilaki yang lebih tinggi dibandingkan perempuan. Kaum laki-laki di daerah Sulawesi
Tenggara memiliki kebiasaan mencari penghidupan (merantau) di luar Provinsi Sulawesi Tenggara (Papua, Maluku, Malaysia, dan lain-lain), sehingga memiliki kemungkinan yang lebih besar untuk terpapar HIV/AIDS, ditambah dengan perilaku yang berisiko tinggi (Haringi et al, 2016).

Pasien pengidap infeksi Human Immunodeficiency Virus (HIV) sering dilaporkan berkaitan dengan adanya perubahan pada metabolisme lipid (Aini et al, 2014). Komplikasi sekunder untuk Antiretroviral (ART) yang sering disebut sebagai sindrom metabolik.

Penelitian yang dilakukan oleh Adewole et al, (2010) menjelaskan bahwa pada orang yang terinfeksi HIV telah menunjukkan berbagai kelainan lipid. Rendahnya tingkat kolestrol total $(C T), H D L$, dan $L D L$ serta trigliserida yang tinggi telah dilaporkan pada infeksi HIV.

Penelitian Mondy et al., (2007) telah mengamati $H D L$ rendah dan trigliserida tinggi pada penderita HIV di Amerika Serikat dan Uganda. Oleh sebab itu, penelitian tentang Profil Lipid Penderita AIDS di Kota Bau-Bau Sulawesi Tenggara perlu dilakukan.

\section{METODE}

Penelitian ini diakukan dengan mengambil sampel pasien yang telah terdiagnosa AIDS dengan menggunakan teknik accidental sampling, dengan metode CFA(Continuous Flow Analyzer). Penelitian ini dilaksanakan pada bulan Juli 2017 dengan jumlah pasien 29 orang. Lokasi penelitian di Laboratorium Rumah Sakit Umum Daerah Kota Bau-Bau Sulawesi Tenggara. Pasien dianjurkan berpuasa selama 8-10 jam.

\section{HASIL DAN PEMBAHASAN}

Penyebaran virus HIV dan penyakit AIDS telah berkembang dengan pesat, hal ini bermula dari beberapa kasus pada populasi tertentu hingga menyebar ke seluruh dunia (Astari et al., 2011). Data saat ini menunjukkan bahwa di negara berkembang penularan secara heteroseksual lebih banyak terjadi dan memicu 
terjadinya infeksi virus HIV (Laksana \& Lestari, 2010)

Tabel 1.Distribusi Penderita AIDS di RSUD Kota Bau-Bau Sulawesi Tenggara Berdasarkan Jenis Kelamin

\begin{tabular}{lll}
\hline $\begin{array}{l}\text { Jenis } \\
\text { Kelamin }\end{array}$ & $\begin{array}{l}\text { Penderita } \\
\text { AIDS }\end{array}$ & Persentase \\
\hline Laki-laki & 19 & 65,5 \\
\hline Perempuan & 10 & 34,5 \\
\hline Jumlah & 29 & 100 \\
\hline
\end{tabular}

Klasifikasi penderita AIDS di RSUD Kota Bau-Bau yang tertera padaTabel 1 dengan kriteria jenis kelamin menunjukkan bahwa jenis kelamin laki-laki lebih banyak yaitu 19 orang $(65,5 \%)$, sedangkan perempuan berjumlah 10 orang $(34,5 \%)$.

Penelitian Saktina \& Satryasa, (2017) menunjukkan bahwa tingginya persentase lakilaki yang menderita HIVIAIDS diasumsikan karena banyaknya laki-laki yang melakukan hubungan seks bebas, napza suntik, dan transfusi darah dibandingkan perempuan yang lebih sering mendapatkan dari pasangan seksual mereka. Ibu rumah tangga yang tertular virus $H I V$ disebabkan karena suami yang sering melakukan hubungan seks bebas. Apabila ibu rumah tangga tersebut sedang hamil maka virus akan ditularkan pada janin yang dikandungnya.

Tabel 2. Distribusi Penderita AIDS di RSUD Kota Bau-Bau Sulawesi Tenggara Berdasarkan Umur

\begin{tabular}{lll}
\hline $\begin{array}{l}\text { Umur } \\
\text { (Tahun) }\end{array}$ & Frekuensi & Persentase (\%) \\
\hline $25-30$ & 9 & 31,03 \\
\hline $31-35$ & 5 & 17,24 \\
\hline $36-40$ & 6 & 20,69 \\
\hline $41-45$ & 7 & 24,13 \\
\hline $46-50$ & 2 & 6,91 \\
\hline Jumlah & 29 & 100 \\
\hline
\end{tabular}

Klasifikasi penderita AIDS di RSUD Kota Bau-Bau Sulawesi Tenggara dengan kriteria kelompok umur tertera pada Tabel 2, terlihat bahwa frekuensi tertinggi pada kelompok umur 25-30 tahun berjumlah 9 orang $(31,03 \%)$, sedangkan terendah pada kelompok umur 46-50 tahun yaitu berjumlah 2 orang (6,91\%).Usia rentan terkena virus HIV 25-30 tahun dikarenakan perilaku usia produktif yang masih banyak dipengaruhi oleh lingkungan, seperti melakukan hubungan seks bebas.

Berdasarkan penelitian Juni \& Ngantung (2012), persentase terbesar kasus HIV terdapat pada golongan umur 20-24 tahun, sedangkan proporsi AIDS terbesar terdapat pada golongan umur 25-29 tahun, dimana merupakan golongan umur remaja dan dewasa muda. Selain itu, kejadian HIV/AIDS pada usia muda sebagian besar melalui hubungan heteroseksual dan perilaku penggunaan alat suntik yang tidak steril secara bergantian.

Perilaku seksual (baik heteroseksual maupun homoseksual) pada usia muda yang tidak terlindungi (tidak menggunakan kondom) banyak ditemukan pada remaja yang aktif secara seksual dan berhubungan dengan banyaknya pasangan.

Menurut Saleh (2012), faktor yang mempengaruhi baik langsung maupun tidak langsung terhadap kejadian infeksi HIV pada usia produktif adalah karakteristik keluarga, yaitu tingkat kestabilan keluarga, komunikasi, dan hubungan dengan orang tua, serta pengawasan orang tua atau keluarga.

Yuliyanasari (2017) menyatakan bahwa infeksi HIV di jaringan memiliki target utama, yaitu sistem imun. Gangguan pada sistem imun mengakibatkan kondisi imuunodefisiensi tubuh menurun. Infeksi HIV dapat menyebabkan penurunan fungsi sistem imun secara bertahap, dimana hal itu terjadi karena depresi sel T pada infeksi HIV. Hasil tersebut menunjukkan High Density Lipoprotein (HDL) rendah dikarenakan kelainan metabolisme dan menurunnya sistem kekebalan tubuh terhadap pasien penderita $A I D S$, sedangkan 
pemeriksaan kadar kolesterol pada penderita AIDS dengan frekuensi 29 orang (100\%) dalam keadaan normal.

Menurut Schaefer et al, (2016), HDL dan LDL memiliki fungsi yang berlawanan. $H D L$ yang terkandung dalam kolesterol biasanya sebanyak 25-30 \% dari total kolesterol. Jumlah yang terbilang sangat sedikit mengingat peranannya yang sangat bermanfaat, $H D L$ termasuk antioksidan dan antiinflamasi serta meningkatkan fungsi untuk memperbaiki metabolisme.

Menurut Klancic et al, (2016) semakin tinggi kadar $L D L$ dalam tubuh akan menurunkan HDL dalam tubuh.HDL rendah meningkatkan faktor risiko untuk penyakit jantung pada pasien $H I V$ positif.

Menurut Kusuma et al, (2015), kolesterol dalam kadar normal jelas berdampak positif bagi tubuh. Namun, bila sudah melewati batas normalakan timbul dampak negatif bagi kesehatan, terutama dalam jangka panjang.

Menurut Kusuma et al, (2015), kadar LDL yang berlebihan dalam darah akanmeningkatkan risiko penumpukan atau pengendapan kolesterol pada dinding pembuluh darah arteri yang diikuti dengan terjadinya aterosklerosis. Oleh karena itu, $L D L$ biasa disebut kolesterol jahat dan menjadi sasaran terapi pencegahan penyakit jantung koroner (PJK), dan stroke. Penyebab penyakit jantung koroner adalah mulai dari terjadinya aterosklerosis maupun yang sudah terjadi penimbunan lemak, baik disertai gejala klinis atautanpa gejala.

Pemaparan yang sama juga dikemukakan oleh Wicaksono (2014), yang menyatakan risiko terjadinya stroke iskemik akan meningkat pada kondisi dimana terjadi peningkatan kadar kolesterol total yang diikuti dengan penurunan kadar HDL. Pada kondisi tersebut, rasio antara kadar kolesterol total terhadap $H D L$ akan naik sehingga dapat memicu terbentuknya aterosklerosis
Tabel 3. Distribusi Penderita AIDS di RSUD Kota Bau-Bau Sulawesi Tenggara Berdasarkan Pofil Lipid

\begin{tabular}{ccccccccc}
\hline & \multicolumn{7}{c}{ Profil Lipid } \\
\cline { 2 - 8 } Usia & Kolesterol & HDL & LDL & Trigiserida \\
\cline { 2 - 8 } & Normal & High & Normal & Low & Normal & High & Normal & High \\
\hline $25-30$ & 9 & 0 & 0 & 9 & 9 & 0 & 0 & 9 \\
\hline $31-35$ & 5 & 0 & 0 & 5 & 5 & 0 & 0 & 5 \\
$36-40$ & 6 & 0 & 0 & 6 & 6 & 0 & 0 & 6 \\
\hline $41-45$ & 7 & 0 & 0 & 7 & 7 & 0 & 0 & 7 \\
$46-50$ & 2 & 0 & 0 & 2 & 2 & 0 & 0 & 2 \\
Total & 29 & 0 & 0 & 29 & 29 & 0 & 0 & 29 \\
\hline
\end{tabular}

Penelitian yang telah dilakukan di RSUD Kota Bau-Bau Sulawesi Tenggara yang tertera pada Tabel 3 menunjukkan kadar trigliserida yang tinggi, kadar $L D L$, dan kolesterol yang normal serta menurunnya kadar $H D L$ dalam tubuh. Hasil pemeriksaan pada penderita AIDS memiliki kadar trigliserida dalam kriteria high (tinggi) yaitu 29 orang (100\%), melebihi nilai rujukan $\leq 200 \mathrm{mg} / \mathrm{dL}$. Pemeriksaan trigliserida pada penderita AIDS mengalami peningkatan dibandingan dengan $H D L, L D L$, dan kolesterol. Putriet al,(2014) menyatakan peningkatan ini dikarenakan mengonsumsi obat-obatan, merokok, dan kurangnya olahraga tertentu merupakan salah satu penyebab tingginya kadartrigliserida. Peningkatan trigliserida adalah faktor risiko terjadinya penyakit jantung koroner dan stroke. Kadar trigliserida tinggi juga cenderung menyebabkan gangguan tekanan darah dan risiko diabetes mellitus.

Penelitian yang dilakukan oleh $\underline{\text { Adewole }}$ et al, (2010) menjelaskan bahwa pada orang yang terinfeksi HIV telah menunjukkan berbagai kelainan lipid. Rendahnya tingkat kolestrol total $(C T), H D L$, dan $L D L$ serta trigliserida yang tinggi telah dilaporkan pada infeksi HIV. Penelitian Mondy et al., (2007) telah mengamati HDL rendah dan trigliserida tinggi pada penderita HIV di Amerika Serikat dan Uganda. 


\section{PENUTUP}

Hasil penelitian menunjukkan bahwa pada penderita AIDS di Kota Bau-Bau Sulawesi Tenggara diperoleh hasil pemeriksaan profil lipid yaitu kadar trigliserida yang tinggi, kadar $L D L$, dan kolesterol normal, serta kadar $H D L$ yang rendah.

\section{DAFTAR PUSTAKA}

Adewole, O. O., Eze, S., Ye, B., Anteyi, E., Wada, I., Ajuwon, Z., \& Erhabor, G. (2010). Lipid profile in HIV/AIDS patients in Nigeria. African Health Sciences, 10(2): 144-149.

Aini, Y. H., Rita, C., Indrati, A. R., \& Wisaksana, R. (2014). T-Cd4+ dan Profil Lipid di HIV. Indonesian Journal of Clinical Pathology and Medical Laboratory, 21(1):50-56.

Ainun, N., Febrina, W., \& Wahyuni, A. (2016). Faktor-Faktor yang Mempengaruhi Perubahan Perilaku Pasien HIV/AIDS. Jurnal Human Care, 1(2). Retrieved from https://www.researchgate.net/publicatio n / 328787763 _ F A K T O R FAKTOR_YANG_MEMPENGARUHI_P ERUBAHAN_PERILAKU_PASIEN_HIV AIDS

Astari, L. dkk. (2009). Viral Load pada Infrksi HIV. Unair, 21(1):31-39.

Dinkes Sultra. (2012). Profil Kesehatan Sulawesi Tenggara Kendari. Kendari.

Haringi, S., Yuniar, N., \& Jufri Nur Nashriana. (2016). Perilaku siswa SMA dalam upaya pencegahan HIV AIDS di wilayah kota Kediri. Jurnal Ilmiah Mahasiswa Kesehatan Masyarakat, 1(3):1-10.

HIV/AIDS. (2010). Jurnal Kesehatan Resproduksi.

Klancic, T., Woodward, L., Hofmann, S. M., \& Fisher, E. A. (2016). High density lipoprotein and metabolic disease: Potential benefits of restoring its functional properties. Molecular Metabolism. Elsevier GmbH. https://doi.org/10.1016/j.molmet.2016.03. 001

Kusuma, I. M., Haffidudin, M., \& Prabowo, A. (2015). Hubungan Pola Makan dengan Peningkatan Kadar Kolesterol Pada
Lansia di Jebres Surakarta. Jurnal Keperawatan Akademika Keperawatan Tujuh Belas Karanganyar, 2(26): 221-276.

Laksana, agung S. dwi, \& Lestari, diyah woro dwi. (2010). Faktor-Faktor Risiko Penularan HIV/AIDS pada Laki-Laki dengan Orientasi Seks Heteroseksual dan Homoseksual di Purwokerto. Mandala of Health, 4(2): 113-123.

Leunupun, S. (2014). INSIDEN PENDERITA HIV/AIDS DENGAN KOMPLIKASI INTRAKRANIAL YANG DIRAWAT OLEH BAGIAN NEUROLOGI DI RSUP PROF. DR. RD KANDOU MANADO. EClini $C$. R e tri e ved from http://ejournal.unsrat.ac.id/index.php/ec linic/article/view/3739

Mondy, K., et al. (2007). Metabolic syndrome in HIV-infected patients from an urban, midwestern US outpatient population. Clinical Infectious Disease, 44(5): 726-734.

Ntim, C. G. (2016). Corporate governance, corporate health accounting, and firm value: The case of HIV/AIDS disclosures in Sub-Saharan Africa. International Journal of Accounting, 51(2): 155-216. https://doi.org/10.1016/j.intacc.2016.04.00 6

Saktina, Putri Uli \& Satriyasa, B. K. (2017). Karakteristik Penderita AIDS dan Infeksi Oportunistik di Rumah Sakit Umum Pusat Sanglah Denpasar Periode Juli 2013 sampai Juni 2014. E-Jurnal Medika, 6(3): $1-6$.

Saleh, I. (2012). Faktor Risiko Infeksi HIV pada Manusia Usia Muda di Klinik Voluntary Counselling and Testing (VCT). Tesis. Yogyakarta.

Santos, D., de Azevedo, K. P. M., Silveira, A. P. K. F., Leitão, J. C., Bento, T., da S. Dantas, P. M., ... Knackfuss, M. I. (2016). Physical Activity and Sleep of Persons Living with HIV/AIDS: A Systematic Review. Revista Andaluza de Medicina Del Deporte, 10(xx), 6-1 1. h tt p s : / / d o i . o r g / http://dx.doi.org/10.1016/j.ramd.2016.08. 001 
Schaefer, E. J., Anthanont, P., Diffenderfer, M. R., Polisecki, E., \& Asztalos, B. F. (2016). Diagnosis and treatment of high density lipoprotein deficiency. Progress in Cardiovascular Diseases. The Authors. https://doi.org/10.1016/j.pcad.2016.08.00 6

Shinta, S. S. (2011). 14 Penyakit Paling Sering Menyerang dan Sangat Mematikan. Yogyakarta: Diva Press.

Wenas Mercilia F., dkk. (2017). Hubungan Antara Rasio Kadar Kolesterol Total
Terhadap High-Density Lipoprotein (HDL) Dengan Kejadian Penyakit Jantung Koroner Akut di RSUP Prof. Dr. R. D. Kandou Manado. Jurnal E-Clinic (ECl), 5(2): 183-188.

Yuliyanasari, N. (2017). GLOBAL BURDEN D E S E A S - H U M A N IMMUNODEFICIENCY VIRUS ACQUIRED IMMUNE DEFICIENCY SYNDROME ( HIV-AIDS ), (October 2016): 65-77. 